\title{
Anti-inflammatory activity of fatty extract of Vitalleria paradoxa Kernel (Shea butter) and pattern of its clinical use in arthritis in Enugu, South East Nigeria
}

\author{
Muoghalu GU. ${ }^{1}$, Akah PA ${ }^{1}$, Okoye TC ${ }^{1}$, Ezenyi IC ${ }^{3}$, Ibeneme S. $^{2}$, Okoli CO$^{1}$
}

\begin{abstract}
${ }^{1}$ Department of Pharmacology and Toxicology, Faculty of Pharmaceutical Sciences, University of Nigeria, Nsukka 410001, Enugu State, Nigeria ${ }^{2}$ Department of Medical Rehabilitation, Faculty of Health Sciences, University of Nigeria, Enugu Campus, Enugu State, Nigeria

${ }^{3}$ Department of Pharmacology and Toxicology, National Institute for Pharmaceutical Research and Development (NIPRD), Idu Industrial Area, Abuja, Nigeria
\end{abstract}

Received: 26 September 2016 Accepted: 26 October 2016

\section{*Correspondence to:}

Dr. Ezenyi IC,

Email: iphie_odike@yahoo.com

Copyright: (c) the author(s), publisher and licensee Medip Academy. This is an openaccess article distributed under the terms of the Creative Commons Attribution NonCommercial License, which permits unrestricted noncommercial use, distribution, and reproduction in any medium, provided the original work is properly cited.

\begin{abstract}
Background: The fatty seed extract of Vitellaria paradoxa Kernel (Sapotaceae) commonly called "Shea butter", is a popular remedy for arthritis in west Africa. This study investigated the knowledge, prevalence and pattern of use of Shea butter in clinically diagnosed arthritic patients as well as its effects on acute (topical and systemic) and chronic inflammation in rodents.

Methods: Knowledge, prevalence and pattern of use were determined using pre-tested questionnaire in clinically diagnosed patients whereas the antiinflammatory activity was studied using xylene-induced mouse ear edema, carrageenan-induced rat paw edema, formaldehyde-induced arthritis in rats and cotton pellet granuloma test in rats.

Results: The results showed that of the 164 respondents, $94.1 \%$ know about Shea butter and $59.6 \%$ have used it mainly as a massage ointment once or twice daily. However, $73.7 \%$ of the users combine this remedy with analgesics to achieve relief. The pharmacological tests showed that topical application of Shea butter inhibited acute edema of the mouse ear. Systemic oral administration caused significant $(\mathrm{p}<0.05)$ suppression of the development of systemic acute edema of the rat paw in a non-dose related manner. Twice daily topical application of Shea butter significantly $(\mathrm{p}<0.05)$ inhibited the edematous response to formaldehyde arthritis whereas once daily administration was not effective. Shea butter also caused a significant $(\mathrm{p}<0.05)$ non-dose related inhibition of granuloma tissue formation on implanted cotton pellets.

Conclusions: These findings provide a scientific rationale for the use of Shea butter in treatment of disorders of inflammation in traditional medicine.
\end{abstract}

Keywords: Anti-inflammatory, Shea butter, Vitellaria paradoxa

\section{INTRODUCTION}

Many people across the globe use complementary and alternative medicine (CAM) as alternative or therapeutic adjunct in coping with debilitating diseases. Research has shown that people suffering from chronic pain and those dissatisfied with current treatment are very likely to seek alternative treatments, and an estimated $60-90 \%$ of persons with arthritis use CAM. ${ }^{1}$ Vitellaria paradoxa (Sapotaceae) commonly called Shea tree, is an indigenous plant of West Africa which resembles an oak (Quercus species) in its general size and form. ${ }^{2}$ The fatty extract from the Shea nut kernel is referred to as Shea butter. It is widely used in cosmetic, baby care, food, confectionary and pharmaceutical industries due to its high content of non-saponifiable lipids and similarity to cocoa butter in terms of composition and crystallization properties. ${ }^{3,4,5}$ Unrefined Shea butter is claimed to be effective against skin rashes, sunburn, blemishes, eczema, small wounds, burns, athlete's foot, insect bites and 
stings, arthritis and muscle fatigue. ${ }^{6}$ In southeast Nigeria, Shea butter is a common remedy for swellings. It is used as massage ointment in arthritis, as cough remedy and nasal decongestant in children. It is also used to enhance hair growth in women.

Shea butter contains high levels of UV absorbing triterpene esters such as cinnamic acids, tocopherol, vitamin A and phytosterols. ${ }^{7}$ The fatty content of the shea nut kernel varies by region from 29.7-53.7\%, while protein content is insignificant. ${ }^{4,8}$ Phytosterols make up an unsaponifiable fraction of Shea butter and these include campesterol, stigmasterol, $\beta$-sitosterol, $\alpha$ spinosterol, triterpenes and a hydrocarbon, karitene. ${ }^{9}$ Shea butter is composed of five principal fatty acids: palmitic, oleic, stearic, linoleic and arachidic acid. ${ }^{10}$ Some of these phytoconstituents have been implicated in the anti-inflammatory activity of plants. Campesterol, stigmasterol, $\beta$-sitosterol, $\alpha$ - and $\beta$-amyrin, ${ }^{11}$ lupeol ${ }^{12,13,14}$ and cinnamic acid ${ }^{14}$ are anti-inflammatory terpenoids present in many plants. Mediators of inflammatory reactions are regulated by nuclear factor $-\kappa \mathrm{B}(\mathrm{NF}-\kappa \mathrm{B}) .{ }^{15}$ $\mathrm{NF}-\kappa \mathrm{B}$ remains in the cytoplasm of resting cells as heterodimeric complexes bound to an inhibitor protein. When activated, an NF- $\mathrm{KB}$-inducing kinase causes phosphorylation of the inhibitor-kinase complex. The succeeding events lead to the synthesis of various inflammatory mediators. ${ }^{16}$ Overproduction of these mediators is implicated in many inflammatory diseases, including rheumatoid arthritis.

This study investigated the antiinflammatory activity of the fatty extract of $V$. paradoxa (shea butter) and ascertained the basis for its use in inflammatory disorders by investigating its anti-inflammatory activity using experimental models of acute and chronic inflammation. The study also involved the determination of the prevalence of Shea butter use amongst clinically diagnosed arthritic patients, using a pre-tested questionnaire.

\section{METHODS}

\section{Animals}

Adult albino rats $(80-230 \mathrm{~g})$ and mice $(15-23 \mathrm{~g})$ of either sex were used. The animals were obtained from the laboratory animal facility of the Department of Pharmacology and Toxicology, University of Nigeria, Nsukka and housed in steel cages under standard conditions with natural lighting within the facility. They were allowed free access to clean drinking water and standard rodent feed. Prior to commencement of experiments, they were acclimatized for 2 weeks to laboratory conditions. Ethical approval was obtained from the ethics committee of the Department of Pharmacology and Toxicology, University of Nigeria, Nsukka. Animal experiments and handling were conducted in accordance with the National Institute of
Health Guide for care and use of Laboratory Animal (pub No. 85-23, revised 1985). ${ }^{17}$

\section{Patients}

Patients that visited National Orthopedic Hospital, Enugu, Nigeria between July and November 2012 and were clinically diagnosed of arthritis were recruited after their informed consent. Patients at all ages and of any gender were included in the study. Patients who complained of arthritis but were yet to present the complaint to the doctor (new patients) and patients with complaints other than arthritis were excluded from the study. Accident victims were also excluded.

\section{Shea butter}

Shea butter produced using local extraction technique was purchased from a dealer in Enugu state; Nigeria. ${ }^{18} \mathrm{It}$ was put in an airtight container and stored at room temperature until used.

\section{Pharmacological activity tests}

\section{Systemic acute inflammation of the rat paw}

The method of Winter et al. was used. ${ }^{19}$ Twenty five rats of either sex were divided into 5 groups of 5 rats each. Groups 1, 2 and 3 were the test groups and received oral administration of 100,200 and $400 \mathrm{mg} / \mathrm{kg}$ respectively of Shea butter suspended in olive oil. Groups 4 and 5 were the control groups and received indomethacin $(10 \mathrm{mg} / \mathrm{kg})$ or equivalent volume of olive oil. One hour after test administration, $0.1 \mathrm{ml}$ of $1 \%$ solution of carrageenan in normal saline was injected into the sub plantar region of the right hind paw. The paw size was measured by volume of distilled water displaced before $(0 \mathrm{~h})$ and at $0.5,1,2,3,4$ and $5 \mathrm{~h}$ after carrageenan injection. Increase in paw volume was calculated as the difference in paw volume at $0 \mathrm{~h}$ and its volume at different times after carrageenan injection. The level of inhibition (\%) of edema was calculated for each group using the relation:

$$
\text { Inhibition }(\%)=100[1-(\mathrm{Vt} / \mathrm{Vc})]
$$

Where $\mathrm{Vt}=$ Average paw volume of the treated group, $\mathrm{Vc}=$ Average paw of the control group.

\section{Topical acute ear edema in mice}

The effect of Shea butter on topical acute inflammation was studied using xylene induced ear edema. Fifteen mice (15-23 g) were divided into 3 groups of 5 mice each. Group 1 received topical application of shea butter (5 mg/ear) while group 2 received indomethacin (10 mg/ear) on the anterior surface of the right ear. Group 3 (control) received topically an equivalent volume of olive oil. Xylene $(0.05 \mathrm{ml})$ was instantly applied on the posterior surface of same right ear for all animals. The left ear was left untreated and served as control. The mice 
were sacrificed $3 \mathrm{~h}$ after xylene application and a circular disc from each ear of uniform diameter punched out with a cork borer $(6 \mathrm{~mm}$ diameter $)$ and weighed. The difference in weight of discs from treated and untreated ears was calculated and used as measured of inflammation. ${ }^{20}$ The level of inhibition $(\%)$ of edema was calculated using the relation:

Inhibition $(\%)=100[1-(\mathrm{Et} / \mathrm{Ec})]$

Where Et = Average edema of the treated group, Ec = Average edema of the control group

\section{Formaldehyde induced arthritis in rats}

The formaldehyde arthritis model of Seyle was used with modification. $^{21} 30$ of either sex (80-230 g) were divided into 6 groups $(n=5)$. The basal right hind paw volume was measured by water displacement. On day 1 of the experiment, groups 1, 2 and 3 were treated by liberal topical application of Shea butter, olive oil and methyl salicylate cream respectively. Inflammation was induced after $30 \mathrm{~min}$. by sub-plantar injection of $0.1 \mathrm{ml}$ of $(2 \% \mathrm{v} / \mathrm{v})$ formaldehyde solution. The paw volume was measured again after $4 \mathrm{~h}$. The animals were then treated once daily for 10 days with a re-challenge with formaldehyde injection on day 3. Measurement by water displacement was also taken daily for 10 days. Animals in groups 4, 5 and 6 received similar treatment but measurement and treatment were taken twice daily (12 hourly) for 10 days. The increase in paw volume was used as a measure of inflammation. The global edematous response to formaldehyde arthritis was quantified as the area under the curve (AUC) of the timecourse of the arthritic event. The AUC was calculated using the trapezoidal rule. The level of inhibition (\%) of edema was calculated using the relation:

Inhibition $(\%)=100[1-(\mathrm{AUCt} / \mathrm{AUCc})]$

Where $\mathrm{AUCt}=\mathrm{AUC}$ of treated groups, $\mathrm{AUCc}=\mathrm{AUC}$ of untreated the control group

\section{Cotton pellet-induced granuloma in rats}

Twenty five rats of either sex were used in this study. The method described by Swingle and Shideman was used. ${ }^{22}$ On day 0 , animals were divided into 5 groups $(n=5)$.Groups 1, 2 and 3 received orally 100, 200 and 400 $\mathrm{mg} / \mathrm{kg}$ of Shea butter respectively. Group 4 received indomethacin $10 \mathrm{mg} / \mathrm{kg}$ doses, while group 5 (control) received an equivalent volume of olive oil. The animals were immediately anesthetized with xylazine (10 $\mathrm{mg} / \mathrm{kg}$ )/ketamine $(50 \mathrm{mg} / \mathrm{kg})$. The axilla region was quickly shaved and cleaned with methylated spirit. Sterile cotton pellets $(20 \mathrm{mg})$ were aseptically inserted in the axilla region of the rats through small subcutaneous incisions of about $1 \mathrm{~cm}$ length on each side of the axilla. The incisions are sutured with sterile nylon. Treatment was continued once daily for 7 consecutive days. On day
8, the animals were sacrificed under anesthesia and the cotton pellets removed. The pellets were freed from extraneous tissues and dried in an oven at $60^{\circ} \mathrm{C}$ for $48 \mathrm{~h}$ and weighed. The net dry weight was determined. The average weight of the pellet of the control group as well as of test groups was calculated. The level of inhibition (\%) of edema was calculated using the relation:

Inhibition $(\%)=100[1-(\mathrm{Et} / \mathrm{Ec})]$

Where Et = Average granuloma weight of the treated group, $\mathrm{Ec}=$ Average granuloma weight of the control group.

\section{Data collection on prevalence of use}

Pre-tested questionnaire was issued to patients with clinically diagnosed arthritis in the Outpatient Department of National Orthopaedic Hospital, Enugu, who after due explanation granted informed consent to participate in the study. The questionnaires were returned after completion on daily basis (Monday-Thursday). A total of 164 arthritis patients responded. Illiterate patients were, however, interviewed based on the content of the questionnaire. The questionnaire comprised of three sections; demographic characteristic of the patient, knowledge of their arthritis condition and Shea butter use pattern.

\section{Statistical analysis}

Data obtained from the questionnaire were analyzed using descriptive statistics. Data obtained from pharmacological tests were analyzed using One Way Analysis of Variance (ANOVA) and subjected to LSD post-hoc test (SPSS version 20). Differences between means were accepted significant at $\mathrm{P}<0.05$. Results were presented as Mean \pm SEM (standard error of mean).

\section{RESULTS}

\section{Demographic characteristics of respondents and their knowledge of arthritis and use of Shea butter}

The demographic data obtained showed that the mean age of the respondents in years was 50.95 (Table 1). A greater proportion of the respondents were female (85\%). Most of the patients seen were educated and were either employed $(50.6 \%)$, or traders $(19.6 \%)$. However some were unemployed $(29.7 \%)$. One hundred and forty five (145) of the 164 respondents were married while 16 were unmarried.

About $94 \%$ of the patients had knowledge of arthritis and were aware that they were experiencing arthritis. Up to $38.3 \%$ had experienced the ailment for over 3 years. Arthritis of the knee and hips had the highest frequency (50.34 and $34.48 \%$ respectively). Respondents acknowledged that arthritic pain worsen at night (49.2\%), in the morning $(33.3 \%)$ and after a long distance walk 
(31.1\%). All the patients made one form of effort or another such as use of orthodox drugs (78\%), herbs $(12.1 \%)$ and massage therapies to manage the pain and swelling associated with their condition.

Table 1: Sociodemographic characteristics of respondents and their knowledge of arthritis and pattern of use of Shea butter.

\begin{tabular}{|c|c|c|}
\hline Characteristic & Variable & Number $(\%)$ \\
\hline \multirow[t]{2}{*}{ Gender } & Female & 65.85 \\
\hline & Male & 34.15 \\
\hline \multirow[t]{3}{*}{ Occupation } & Civil servants & 50.63 \\
\hline & Traders & 19.62 \\
\hline & Unemployed & 29.75 \\
\hline \multirow[t]{2}{*}{$\begin{array}{l}\text { Knowledge of } \\
\text { disease condition }\end{array}$} & Yes & 94.44 \\
\hline & No & 5.56 \\
\hline \multirow[t]{4}{*}{$\begin{array}{l}\text { Part of body } \\
\text { affected by arthritis }\end{array}$} & Knees & 50.34 \\
\hline & Hips & 34.48 \\
\hline & $\begin{array}{l}\text { Arms and } \\
\text { fingers }\end{array}$ & 13.79 \\
\hline & Toes & 1.39 \\
\hline \multirow[t]{4}{*}{$\begin{array}{l}\text { Factors that worsen } \\
\text { arthritic pain }\end{array}$} & $\begin{array}{l}\text { Long distance } \\
\text { walk }\end{array}$ & 37.78 \\
\hline & $\begin{array}{l}\text { Sitting for a } \\
\text { long while }\end{array}$ & 27.41 \\
\hline & Cold weather & 25.19 \\
\hline & Others & 9.63 \\
\hline \multirow[t]{2}{*}{$\begin{array}{l}\text { Knowledge of Shea } \\
\text { butter use }\end{array}$} & Yes & 94.1 \\
\hline & No & 5.9 \\
\hline \multirow[t]{3}{*}{ Mode of use } & $\begin{array}{l}\text { As massage } \\
\text { ointment }\end{array}$ & 63.7 \\
\hline & As cream & 28.4 \\
\hline & By mouth & 7.9 \\
\hline \multirow[t]{3}{*}{ Frequency of use } & Twice daily & 48.9 \\
\hline & Once daily & 42.6 \\
\hline & Thrice daily & 8.5 \\
\hline \multirow[t]{2}{*}{$\begin{array}{l}\text { Duration of pain } \\
\text { relief after Shea } \\
\text { butter use }\end{array}$} & $\leq 1$ hour & 78.3 \\
\hline & $>1$ hour & 21.7 \\
\hline
\end{tabular}

On the knowledge and use of Shea butter, $94.1 \%$ of the patients had heard of Shea butter while only $59.6 \%$ of them had used it. Majority of the users $(63.7 \%)$ used it as a massage ointment once $(42.6 \%)$ or twice $(48.9 \%)$ daily. Also, majority of the users $(76.9 \%)$ used it for 6 months or more. Up to $80 \%$ of the users admitted getting relief in form of reduction in pain $(71 \%)$ mainly for periods of more than one hour $(78.3 \%)$. Some of the users $(73.7 \%)$ combine Shea butter use with other massage therapies or drugs especially analgesics $(68.2 \%)$. Most of the users $(91.3 \%)$ obtain relief when they use Shea butter with other remedies.

\section{Effect of Shea butter on systemic acute inflammation}

Single oral administration of Shea butter inhibited the development of systemic acute edema of the rat paw. The inhibitory effect was non- dose dependent but significant $(\mathrm{p}<0.05)$ within $1 \mathrm{~h}$ post administration of carrageenan (Table 2).

\section{Effect of Shea butter on topical acute inflammation}

Topical administration of Shea butter inhibited the acute edema of the mouse ear induced with xylene. However, the inhibitory effect was not significant $(\mathrm{p}<0.05)$ but comparable to that of indomethacin (Table 3 ).

\section{Effect of Shea butter on experimental arthritis}

Shea butter was ineffective in inhibiting the development of arthritis. However, twice daily application caused inhibitory effects seen as a reduction of the area under curve (AUC). Its effect was greater than that produced by methyl salicylate (Table 4).

\section{Effect of Shea butter on granuloma formation}

Shea butter caused a significant $(\mathrm{P}<0.05)$ inhibition of granuloma tissue growth on the implanted cotton pellets. The effect was dose-dependent and less than the inhibition caused by indomethacin (Table 5).

\section{DISCUSSION}

Findings from our study show that majority of the respondents in this study were females, showing that women are more likely to have arthritis than men. Arthritis is a common disease with peak incidence in third to fourth decades of life and its incidence is 3 to 5 times higher in females. ${ }^{23,24}$ Many of the patients also affirmed that the pain worsens on taking a long distance walk which is consistent with osteoarthritis. Patients with arthritis of the knee and hip were in the majority which indicates a non-inflammatory arthritis. ${ }^{25}$ Rheumatoid arthritis affects only about $1 \%$ of the population. ${ }^{25}$ Thus; the number of these patients with arthritis suggests these may be more of osteoarthritis cases than other forms of arthritis. As most of the patients were females and married, child bearing and body weight of the patients could be factors in osteoarthritis. Obesity is a major modifiable factor in arthritis. ${ }^{26}$

Shea butter is a common traditional remedy for arthritic pains and swellings in southeastern Nigeria. It was therefore expected that most of the patients would have heard about it and used it. Evidence in this study further shows that use of Shea butter is a common practice among subjects with arthritis. The nature of relief obtained from the use of Shea butter alone is obviously insufficient and of short duration to adequately relieve pain associated with the chronic condition. This may explain why it is usually combined with other therapies 
or drugs especially analgesics to achieve better and more prolonged pain relief. Experimental evaluation of the anti-inflammatory action of Shea butter in rodents showed that it inhibited both acute and chronic inflammation on topical and systemic administration. Shea butter is a fatty extract and its lipophilic nature may have enabled it to cross the skin membrane barrier and exert action on topical application, possibly by inhibiting the release of mediators in the acute phase of inflammation. Xylene is an irritant and causes acute fluid accumulation and edema. The edema induced by phlogistic substances on the mouse ear is an acute inflammatory response mediated by a variety of agents such as leukocytes and prostanoids. ${ }^{27}$

Table 2: Effect of shea butter on systemic acute edema of the rat paw.

\begin{tabular}{|c|c|c|c|c|c|c|c|}
\hline \multirow{2}{*}{ Treatment } & \multirow{2}{*}{$\begin{array}{l}\text { Dose } \\
(\mathrm{mg} / \mathrm{kg})\end{array}$} & \multicolumn{6}{|l|}{ Edema (ml) } \\
\hline & & $0.5 \mathrm{~h}$ & $1 \mathrm{~h}$ & $2 \mathrm{~h}$ & $3 \mathrm{~h}$ & $4 \mathrm{~h}$ & $5 \mathrm{~h}$ \\
\hline \multirow[t]{3}{*}{ Shea butter } & 100 & $\begin{array}{l}0.26 \pm 0.09 * \\
(59.38)\end{array}$ & $\begin{array}{l}0.44 \pm 0.15 * \\
(29.03)\end{array}$ & $\begin{array}{l}0.50 \pm 0.17 \\
(3.85)\end{array}$ & $\begin{array}{l}0.52 \pm 0.11 \\
\mathrm{NI}\end{array}$ & $\begin{array}{l}0.38 \pm 0.08 \\
(17.4)\end{array}$ & $\begin{array}{l}0.56 \pm 0.15 \\
\text { NI }\end{array}$ \\
\hline & 200 & $\begin{array}{l}0.16 \pm 0.05 * \\
(75.00)\end{array}$ & $\begin{array}{l}0.36 \pm 0.18 \\
(41.94)\end{array}$ & $\begin{array}{l}0.42 \pm 0.17 \\
(19.24)\end{array}$ & $\begin{array}{l}0.40 \pm 0.21 \\
(23.08)\end{array}$ & $\begin{array}{l}0.40 \pm 0.16 \\
(13.04)\end{array}$ & $\begin{array}{l}0.36 \pm 0.25 \\
(14.29)\end{array}$ \\
\hline & 400 & $\begin{array}{l}0.26 \pm 0.11 * \\
(59.38)\end{array}$ & $\begin{array}{l}0.48 \pm 0.13 \\
(22.58)\end{array}$ & $\begin{array}{l}0.42 \pm 0.08 \\
(19.24)\end{array}$ & $\begin{array}{l}0.50 \pm 0.19 \\
(3.85)\end{array}$ & $\begin{array}{l}0.36 \pm 0.11 \\
(21.74)\end{array}$ & $\begin{array}{l}0.32 \pm 0.22 \\
(23.81)\end{array}$ \\
\hline Indomethacin & 10 & $\begin{array}{l}0.14 \pm 0.09 * \\
(78.12)\end{array}$ & $\begin{array}{l}0.18 \pm 0.08 * \\
(70.97)\end{array}$ & $\begin{array}{l}0.26 \pm 0.11 * \\
(50.00)\end{array}$ & $\begin{array}{l}0.14 \pm 0.11 * \\
(73.08)\end{array}$ & $\begin{array}{l}0.10 \pm 0.10 * \\
(78.26)\end{array}$ & $\begin{array}{l}0.18 \pm 0.11 * \\
(57.14)\end{array}$ \\
\hline Control & 2.5 & $0.64 \pm 0.05$ & $0.62 \pm 0.11$ & $0.52 \pm 0.13$ & $0.52 \pm 0.13$ & $0.46 \pm 0.15$ & $0.42 \pm 0.11$ \\
\hline
\end{tabular}

$\mathrm{n}=5$; $* \mathrm{P}<0.05$ compared to control (One way ANOVA; LSD post hoc test); Values shown are Mean \pm SEM; Values in parenthesis are Inhibition (\%) calculated relative to the Control.

Table 3: Effect of shea butter on acute ear edema in mice.

\begin{tabular}{|llll|}
\hline Treatment & $\begin{array}{l}\text { Dose } \\
\text { (mg/ear) }\end{array}$ & $\begin{array}{l}\text { Edema } \\
\text { weight(mg) }\end{array}$ & $\begin{array}{l}\text { Inhibition } \\
(\%)\end{array}$ \\
\hline Shea butter & 5 & $8.2 \pm 1.36$ & 21.15 \\
\hline Indomethacin & 5 & $8.4 \pm 1.03$ & 19.23 \\
\hline Control & - & $10.4 \pm 2.23$ & - \\
\hline
\end{tabular}

$\mathrm{n}=5$; Values shown are Mean \pm SEM; Percent inhibition was calculated relative to the control.

Table 4: Effect of shea butter on global edematous response to formaldehyde arthritis.

\begin{tabular}{|c|c|c|c|}
\hline \multirow{3}{*}{ Treatment } & \multicolumn{3}{|l|}{$\mathrm{AUC}(\mathrm{ml} / \mathrm{d})$} \\
\hline & \multirow{2}{*}{$\begin{array}{l}\text { Once } \\
\text { Daily }\end{array}$} & \multicolumn{2}{|l|}{ Twice daily } \\
\hline & & Morning & Evening \\
\hline Shea butter & $\begin{array}{l}4.18 \pm 0.36 \\
(\mathrm{NI})\end{array}$ & $\begin{array}{l}2.51 \pm 0.52 \\
(22.53)\end{array}$ & $\begin{array}{l}2.12 \\
\pm 0.44 * \\
(26.39)\end{array}$ \\
\hline $\begin{array}{l}\text { Methyl } \\
\text { salicylate }\end{array}$ & $\begin{array}{l}3.78 \pm 0.41 \\
(\mathrm{NI})\end{array}$ & $\begin{array}{l}3.78 \pm 0.37 \\
(\mathrm{NI})\end{array}$ & $\begin{array}{l}3.40 \pm 0.44 \\
(\mathrm{NI})\end{array}$ \\
\hline Control & $3.62 \pm 0.42$ & $3.24 \pm 0.43$ & $2.88 \pm 0.32$ \\
\hline
\end{tabular}

$\mathrm{n}=5 ; * \mathrm{P}<0.05$ compared to control (One Way ANOVA; LSD post hoc test); Values shown are Mean \pm SEM; Values in parenthesis are Inhibition (\%) calculated relative to the Control; $\mathrm{AUC}=$ Area Under Curve.
Table 5: Effect of shea butter on granuloma formation.

\begin{tabular}{|c|c|c|c|}
\hline Treatment & $\begin{array}{l}\text { Dose } \\
\text { (mg/kg) }\end{array}$ & $\begin{array}{l}\text { Granuloma } \\
\text { weight } \\
\text { (mg) }\end{array}$ & $\begin{array}{l}\text { Inhibition } \\
(\%)\end{array}$ \\
\hline Shea butter & 100 & $51.9 \pm 3.62 *$ & 28.9 \\
\hline & 200 & $56.2 \pm 4.60 *$ & 23.01 \\
\hline & 400 & $56.3 \pm 2.88 *$ & 22.88 \\
\hline Indomethacin & 10 & $38.2 \pm 0.85^{*}$ & 47.67 \\
\hline Control & - & $73.0 \pm 8.29$ & - \\
\hline
\end{tabular}

inhibition was calculated relative to the Control.

In systemic edema of the rat paw, the anti-inflammatory effect of Shea butter started to wane beyond one hour post-induction of edema. This suggests that the fatty extract may be more effective in suppressing the initial phase of acute inflammatory response. The first phase of this acute inflammatory response in the rat paw begins at about one hour after challenge and has been known to be mediated by massive release of histamine and serotonin. The second phase starts at about three hours after challenge and attributed to bradykinin, prostaglandins and lysozymes. ${ }^{28}$ Therefore, the acute anti-inflammatory effect of Shea butter may be largely due to antihistaminic action. The rapid onset of anti-inflammatory effect may 
be responsible for the reduction in pain within $1 \mathrm{hr}$ experienced by the patients who use it.

In chronic inflammation of the formaldehyde arthritis, Shea butter reduced edema in arthritic rats when it was applied twice daily. Single daily application was ineffective in reducing edema in the arthritic rats. The reason for this is not clear but may not be unrelated to the brief action noticed in systemic acute inflammation. It may also be the reason the patients who use it apply it more than once daily to obtain relief. Chronic inflammation usually arises as a consequence of incomplete elimination or containment of the proinflammatory stimuli by acute inflammation and is usually marked by neutrophil infiltration, fluid exudation and fibroblast proliferation amongst others. Formaldehyde is a potent edematous agent and produces inflammation through the release of several inflammatory mediators including prostaglandins. ${ }^{29}$ Inhibition of the edematous response to formaldehyde provides a scientific basis for the traditional use of Shea butter in the management of chronic inflammation. The cotton pellet induced granuloma was used to study the transudative and proliferative phase of chronic inflammation. ${ }^{19}$ Chronic inflammation often progresses to the development of proliferative cells which can spread or form granuloma. Granuloma tissue formed on an inert foreign body in a dead space comprises an accumulation of modified macrophages and other cells and tissues. Granulomatous inflammation is a prolonged process often involving the mononuclear cells. Though the exact mechanism of anti-inflammatory activity of Shea butter is unknown, its effect in this type of inflammation is an indication of anti-proliferative action. Shea butter is rich in anti-inflammatory phytochemical constituents which may contribute to its effects in this study. Alpha amyrin and $\beta$ - amyrin are triterpenoids found to possess profound anti-inflammatory activity as well as the triterpenes cinnamic acid and lupeol. ${ }^{11,14}$ Terpenoids are reported to be natural inhibitors of $N F-\kappa B$, signaling their inhibitory potentials on inflammation and cancer. ${ }^{30}$ The antiinflammatory action of sesquiterpenes also present in Shea butter has been attributed to inhibition of arachidonic acid metabolism. ${ }^{31}$ The diverse effects of these phytochemical constituents identified in Shea butter on the inflammatory response pathways may account for its anti-inflammatory actions.

This study revealed that Shea butter, the fatty extract of $V$. paradoxa kernel is popular and commonly used among arthritis patients in south-eastern Nigeria. The extract possesses anti-inflammatory actions in both acute and chronic inflammation which can be attributed to the plethora of phytoconstituents that inhibit diverse aspects of the inflammatory response pathway.

Funding: No funding sources
Conflict of interest: None declared

Ethical approval: The study was approved by the Institutional Ethics Committee

\section{REFERENCES}

1. Rao J, Mihaliak K, Kroenke K, Bradley J, Tierney W, Weinberger M. Use of complementary therapies for arthritis among patients of rheumatologists. Ann Intern Med. 1999;131:409-16.

2. Orwa C, Mutua A, Kindt R, Jamnadass R, Anthony S. Agroforestry Database: A tree reference and selection guide version 4.0, 2009. Available at http://www.worldagroforestry.org/ sites/treedbs/treedatabases.asp. Accessed 11 January 2015.

3. Abidemi TA, Adebayo OJ, Idowu O, Agbotoba MO. Nutrient content and anti-nutritional factors in shea butter (Butryospermum parkii) leaves. Afr J Biotechnol. 2009;8:5888-90.

4. Akihisa T, Kojima N, Katoh N, Ichimura Y, Suzuki H, Fukatsu $M$ et al. Triterpene alcohol and fatty acid composition of Shea nuts from seven African countries. J Oleo Sci. 2010;59:351-60.

5. George C, Shams AN, Dunkel FV. Lessons Learned in an International Service-Learning Collaborative: Shea Butter Case Study. North American Colleges and Teachers of Agriculture Journal. 2011;5(2).

6. Wan JP, Wakelyn PJ. Gregory Oil Refining, Illinois, AOCS Press; 1997:142-146.

7. Weisman Z, Maranz S, Bianchi G, Biagaard J. Chemical analysis of fruit of Vitellaria paradoxa In: Improved management of Agroforestry parkland system in SubSahara Africa. Final report, School of Agriculture and Forest science, University of Wales; 2003:131-139.

8. Chawla KK, Bencharitiwong R, Ayuso R, Grishina G, Nowak-Węgrzyn A. Shea butter contains no IgEbinding soluble proteins. J Allergy Clin Immunol. 2011;127:680-2.

9. Badifu GIO. Lipid composition of Nigerian Butyrospermum paradoxum kernel. J Food Compos Anal. 1989;2:238-44.

10. Maranz S, Wiesman Z, Bisgaard J, Bianchi G. Germplasm resources of Vitellaria paradoxa based on variations in fat composition across the species distribution range. Agroforestry Systems. 2004;60:71-6.

11. Okoye NN, Ajaghaku DN, Okeke HN, Ilodigwe EE, Nworu CS, Okoye FB. Beta-amyrin and alpha-amyrin acetate isolated from stem bark of Alstonia boonei display profound anti inflammatory activity. Pharm Biol. 2014;52:1478-86.

12. Fernández MA, de las Heras B, García MD, Sáenz MT, Villar A. New insights into the mechanism of action of the anti-inflammatory triterpene lupeol. J Pharm Pharmacol 2001;53:1533-39.

13. Fernández A, Alvarez A, García MD, Sáenz MT. Antiinflammatory effect of Pimenta racemosa var. ozua and isolation of the triterpene lupeol. Farmaco. 2001;56:33538.

14. Saleem, M. Lupeol, a novel anti-inflammatory and anticancer dietary triterpene. Cancer Lett. 2009;285:109-15. 
15. Chen F, Demers LM, Shi X. Upstream signal transduction of NF- $\kappa \mathrm{B}$ activation. Curr Drug Targets Inflamm Allergy. 2002;1:137-49.

16. Ghosh S, Karin M. Missing pieces in the NF- $\kappa B$ puzzle. Cell. 2002;109:81-96.

17. National Institutes of Health. Guide for the Care and Use of Laboratory Animals, 8th ed. Bethesda MD; 2011.

18. National Research Council. Shea. In: Lost crops of Africa: volume II: Vegetables. Washington DC: National Academies Press; 2006:302-321.

19. Winter CA, Risley EA, Nuss GW. Carrageenan induced edema in hind paw of rat as an assay for antiinflammatory drugs. Proc Soc Exp Biol Med. 1962;111:544-7.

20. Attah AH, Alkohafi A. Anti-nociceptive and antiinflammatory effects of some Jordanian medicinal extracts. J Ethnopharmacol. 1998;60:117-24.

21. Selye H. Further studies concerning the participation of adrenal cortex in the pathogenesis of arthritis. Brit Med J. 1949;2:1129.

22. Swingle KF, Shideman FE. Phases of the inflammatory response to subcutneous implantation of a cotton pellet and their modification by certain anti-inflammatory agents. J Pharmacol Exp Ther. 1972;183:226-34.

23. Mohan, H. Inflammation and healing In: Textbook of pathology. New Dehli: JP publisher; 2006: 133-179.
24. Shikha S. Experimental animal models of rheumatic arthritis. Biotech Articles. 2010;8(21):19.

25. Godman, H. Inflammatory vs. non-inflammatory arthritis: what is the difference? Available at http://www.healthline.com. Accessed 11 January 2015.

26. Wilkins K. Arthritis and excess weight. Statistic Canada Catalogue 82-003. Health Reports. 2004;15:39-51.

27. Tubaro A, Dri P, Delbello G, Zilli C, Della LR. The croton oil ear test revisited. Agent Actions. 1986;17:347-349.

28. Willoughby DA, Flower RJ. The anti-inflammatory action of the salicylates. In: Vane JR, Botting RM, eds. Aspirin and other salicylates. New York NY: Chapman and Hall Medical; 1993:141-159.

29. Tjolsen A, Berge O, Hunskaar S, Rosland JH, Hole K. The formalin test: An evaluation of the method. Pain. 1992;51:5-14

30. Salminen A, Lehtonen M, Suuronen T, Kaarniranta K, Huuskonen J. Terpenoids: Natural inhibitors of NFkappa B signaling with anti-inflammatory and anticancer potential. Cell Mol Life Sci. 2008;65:297999.

31. Kumar S, Baywa BS, Kuldeip S, Kalia AN. Antinflammatory activity of herbal plants: A review. Int J Adv Pharm Biol Chem. 2013;2:271-82.

Cite this article as: Muoghalu G, Akah PA, Okoye TC, Ezenyi IC, Ibeneme S, Okoli CO. Antiinflammatory activity of fatty extract of Vitalleria paradoxa Kernel (Shea butter) and pattern of its clinical use in arthritis in Enugu, South East Nigeria. Int J Basic Clin Pharmacol 2016;5:2345-51. 